\title{
GENETIC IMPROVEMENT OF FERTILITY IN SHEEP BY SELECTION ACCORDING TO PHYSIOLOGICAL PARAMETERS**
}

\author{
M.P. Petrović ${ }^{1 *}$, D. Ružić-Muslić ${ }^{1}$, M. Žujović ${ }^{1}$, C. Mekić ${ }^{2}$ \\ ${ }^{1}$ Institute for Animal Husbandry, Belgrade-Zemun, Serbia \\ ${ }^{2}$ Faculty of Agriculture, Belgrade-Zemun, Serbia \\ *Corresponding author, e-mail: petmilan@eunet.yu \\ **Plenary invited paper. Research financed by the Ministry of Science of Republic of Serbia, \\ Project TR 6858
}

\begin{abstract}
In this paper, fertility parameters of sheep are discussed and principles analyzed in order to obtain the optimal methods for their evaluation. Mathematical procedures for evaluation of genetic and phenotypic parameters and anticipation of genetic values, today, are mainly based on different linear and non-linear concepts, therefore it is necessary to accept the reality that there is no absolute accuracy. Special emphasis is on the possibility of use of physiological quantitative fertility indicators in sheep selection, considering that there is correlation between them and fertility traits. In this regard, the degree of response to direct and indirect selection within population is analyzed in order to established the nature of parameters necessary for evaluation of data and determine the relative degree of such response.
\end{abstract}

Key words: sheep, fertility, selection, physiological parameters

\section{Introduction}

In modern sheep production, most of the income is realized by production and selling of lambs. Therefore, the emphasis in sheep production is on early maturation and reproductive efficiency of individual animals. At the same time, genetic potential of reared populations has to satisfy high criteria (Petrović, 2007).

It is considered that improvement of sheep in future has to provide early maturation in sheep, so that the first fertilization occurs at the age of 6 to 7 months. Also, seasonal character of the oestrus incidence and lactation has to be eliminated and fertility has to exceed two lambs per sheep and partus. 
In order to achieve these high objectives, permanent genetic improvement of traits which are of interest to breeders is necessary (Lewis et al., 1996, Okut et al., 1999, Sakul et al., 1999, Bromley et al., 2000, Petrović et al., 2003, 2004, 2005, 2006 ).

Development of theoretical procedures and discovering of optimal methods for evaluation of genetic fertility parameters is of special interest (Rao et al., 2000, Notter et al., 2000, 2001, 2002, Banos et al., 2002, Duguma et al., 2002, Hanford et al., 2002). Especially since hormones responsible for sheep fertility are under strict genetic control (Zarazaga, 1998, Notter and Chemineau 2001).

Objective of this review is to indicate the nature of fertility factors in sheep and possibilities for use of physiological quantitative parameters in selection.

\section{Analysis of sheep fertility factors}

Number of offspring obtained per lambing is one of the most important parameters of sheep productivity, and according to some authors (Sakul et al., 1999, Petrović, 2000) it is more important than gain, i.e. mass of lambs. This means that biological efficiency of sheep in regard to meat, milk and wool production is conditioned by fertility, i.e. reproductive potential (Greet et al., 1995, Notter et al., 2000).

At he beginning of development of genetics, farmers, relying on the heredity, supported the thesis that increase of fertility by methods of genetics was moderate and insufficiently efficient (Petrović et al.,1993). In spite of such conception, later communications and latest researches on results of selection in sheep on fertility (Rao et al., 2000) have changed this view considerably.

All of the facts mentioned above, as well as presence of less known fertile sheep breeds such as Finnish and Romanov sheep, create assumptions that by methods of programmed breeding work, genetic potential of sheep fertility can lead to higher level, in range from one to three lambs per head and partus.

Success in selection of sheep in regard to their fertility greatly depends on genetic variability of reproductive components (Petrović, 1992, Petrović et al., 1997, 2001, 2002).

Heritability for onset of puberty is low and within the interval of 0,1 to 0,26 (Petrović, 2000).

Expression of oestrus and duration of breeding season in sheep is also of great importance for total sheep production, since certain sheep breeds have 
so called extended sexual season: Romanov sheep Finnish sheep, D'man, which is almost aseasonal.

Beside differences in sexual season in certain sheep populations, the presence of difference in heritability with values from 0,17 to 0,25 was observed (Petrović, 2000).

Range or norm of ovulation in sheep is still great challenge for the science, regardless of the fact that it is generally known that it is under control of larger number of genes, i.e. its poligeneous character. Activities directed to gene identification responsible for this trait are in progress (Galloway et al., 2000, Davis et al., 2001, Grant et al., 2001, Wilson et al., 2001). The presence of high variability of ovulation rate between certain breeds was established. So, average ovulation rate in Merino breed is 1,2 and in Cambridge population even 5,3 (Bindon et al., 1996).

Heritability values for ovulation rate are different and vary from 0,05 in Merino breeds in Australia to 0,50 in Finnish breed in Ireland, and heritability for this trait is 0,21 and repeatability 0,37 with high coefficient of variation (30\%) (Petrović, 2000).

For traits of sheep fertility, of great importance is also embryonic mortality, which is especially present during first four weeks of pregnancy, when $20-30 \%$ of fertilized egg cells can be lost, and which is in negative correlation with ovulation rate (Perez et al., 1994).

Embryonic mortality is trait of low heredity, considering that heritability has value of 0,07 . This means that genetic factors play small role compared to total variability of all effects in population.

\section{Evaluation of genetic fertility parameters}

Evaluation of genetic parameters which are of importance for increase of fertility in sheep is subject of constant discussions and scientific analysis (Van Wyk et al., 2002, Petrović, 2006). The same question is asked over and over: which method of evaluation of genetic fertility parameters is optimal for given population in certain rearing conditions?

Mathematical procedures for evaluation of genetic and phenotypic parameters and prediction/anticipation of genetic values are based on different concepts. For instance, beside linear also non-linear procedures for evaluation of genetic parameters are used (Matos et al., 1997, Gabrilidis et al., 2000, Petrović, 2000) which tells us that there is still no completely reliable method for evaluation.

Fertility traits are conditioned by many limiting factors and occur only in sexually mature animals. Generation interval is long and heritability low. 
This, however, imposes the need for discovering suitable traits which can be used for evaluation or anticipation of individual's genotype before sexual maturity (Petrović et al., 2005).

Considering mentioned factors, our attention should be directed to physiological sheep traits, first of all hormone, metabolite or ferment levels.

\section{Selection according to physiological parameters}

Use of physiological quantitative parameters in sheep improvement in order to realize increased fertility is reasonable only within the population and if adequate data exist. Accordingly, we shall analyze the principles of the degree of response on direct and indirect selection within population in order to establish what kind of parameters are necessary for evaluation of data and determine relative degrees of such responses.

If trait 1 is marked as fertility which has to be improved, and trait 2 as physiological component, than trait 1 has following parameters:

$h 1^{2}$ - Heritability

$\delta \mathrm{P} 1^{2}$ - Phenotypic variance

P1 - Phenotypic value

$\delta \mathrm{A} 1^{2}=\mathrm{h} 1^{2} \delta \mathrm{P} 1^{2}$ - Additive genetic variance

A1 - Breeding value

Trait 2 would have the same parameters, as for instance h2 $2^{2}, \mathrm{P} 2$ etc. Also, in both traits the following is included:

rA - Genetic correlation (or rA12)

$\mathrm{COVA}=\mathrm{rA} \delta \mathrm{A} 1 \delta \mathrm{A} 2-$ Genetic covariance

$\mathrm{rP}-$ Phenotypic correlation

$\mathrm{COVP}=\mathrm{rP} \delta \mathrm{P} 1 \delta \mathrm{P} 2-$ Phenotypic covariance

$\mathrm{SI}-$ Selection index

rASI - Correlation between selection index and breeding value

$\mathrm{i}-$ Selection intensity

Use of standard and equivalent formulas/equations it is possible to describe selection response.

As a result of direct or immediate selection in regard to the own productivity of sheep $\mathrm{P} 1$, the response of fertility trait $(\mathrm{R})$ would be:

$$
\mathrm{R}_{1}=\mathrm{i} \mathrm{h}_{1}{ }^{2} \delta \mathrm{P}_{1}=\mathrm{i} \mathrm{h}{ }_{1} \delta \mathrm{A}_{1}=\delta^{2} \mathrm{~A}_{1} / \delta \mathrm{P}_{1}
$$


Reaction of the connection of fertility traits, as consequence of selection, in physiological quantitative changes $\mathrm{P}_{2}$, will be like this:

$$
\mathrm{R}_{1}=\mathrm{irAh}_{1} \mathrm{~h}_{2} \delta \mathrm{P}_{1}=\operatorname{irAh}_{2} \delta \mathrm{A}_{1}=\mathrm{iCOV}_{\mathrm{A}} / \delta \mathrm{P}_{2}
$$

Reaction of the connection of fertility traits, as a result of selection, according to index of any trait or their combinations has the following form:

$$
\mathrm{R}_{1}=\operatorname{irA} \delta \mathrm{A}_{1}=\mathrm{iCOV}\left(\mathrm{A}_{1}, \mathrm{SI}\right) / \delta_{1}
$$

It is obvious that equations 1 and 2 represent specific cases of equation 3 , for direct selection $\mathrm{SI}=\mathrm{P} 1$, with accuracy of the index $\mathrm{rASI}=\mathrm{h} 1$, and for indirect selection $\mathrm{SI}=\mathrm{P} 2$, i.e. $\mathrm{rASI}=\mathrm{rA} \mathrm{h} 2$.

The next important case is, when selection is carried out based on average of the productivity of female breeding animals, selection of rams according to average level of fertility of n-daughter:

$$
r A S I=\frac{1}{2} h 1\left(\frac{n}{1+(n-1) t 1}\right)^{1 / 2}, \text { where }
$$

t1 - Intraclass correlation of half siblings.

When there is no correlation of the mean for brothers, than $\mathrm{t} 1=1 / 4 \mathrm{~h} 1^{2}$ and $\mathrm{rASI} \rightarrow 1$, and in case of increase of the size of progeny group, $\mathrm{rASI} \rightarrow 1 / 2$ $\mathrm{h} 1 / \sqrt{t} 1$.

If selection of rams is performed based on productivity of half sisters, coefficient $1 / 2$ in equation 4 is changed into $1 / 4$. Relative efficiency of direct and indirect selection, in equal intensity, for specific animals would be:

$$
\frac{R_{1} \text { indirektna }}{R_{1} \text { direktna }}=\frac{r A \mathrm{~h}_{2}}{\mathrm{~h}_{1}}=\frac{C O V A \delta P_{1}}{\delta^{2} \mathrm{~A}_{1} \delta \mathrm{P}_{2}}
$$

Efficiency of selection of rams based on physiological parameters, when own data are considered, level of observed traits in half brothers or daughters, with application of previous equations (2, 3 and 4$)$, is proportional: 


$$
\left(r A \mathrm{~h}_{2} / \mathrm{h}_{1}\right)\left(\frac{n}{1+(n-1) \mathrm{t}_{1}}\right)^{-1 / 2}
$$

In previous considerations the possibility of return use of data wasn't considered. In case of genetic correlation between each subsequent observations, when same genes are expressed and each observation has the same variance and covariance with other traits in the equation, patterns/forms can be modified in the following way:

$$
\begin{gathered}
\delta^{2} \mathrm{P}_{1} \text { as }\left(\mathrm{C}_{1}+\left(1-\mathrm{C}_{1}\right) / \mathrm{n}\right) \delta^{2} \mathrm{P}_{1}, \\
\mathrm{~h}^{2}{ }_{1} \text { as } \mathrm{h}^{2}{ }_{1} /\left(\mathrm{C}_{1}+\left(1-\mathrm{C}_{1}\right) / \mathrm{n}\right. \text {, where: }
\end{gathered}
$$

$\mathrm{C} 1$ - Repeatability (intraclass correlation) between each of $\mathrm{n}$ repeated observation of the trait 1 . For trait 2 analogue form/equation is derived, but $\delta \mathrm{A}^{2}$ in case of both traits 1 in COVA, i.e. rA for trait 2 are not changed. It is also necessary to consider, beside what is mentioned, changes occurring in generation interval.

If from observation to observation genetic expression of trait is altered, for instance, size of litter per lambing or hormone level in cycle stages, than components are entered into index separately.

By bringing together information regarding size of litter and physiological parameters, the selection index can be constructed. So, in index for selection of female breeding animals, using own fertility results (trait 1 in index) and physiological parameters (trait 2), the valuations are needed: $\delta \mathrm{P} 1^{2}, \delta^{2} \mathrm{P} 2^{2}$ and COVP for phenotypic covariance of matrix, as well as evaluation $\delta \mathrm{A} 1^{2}$ COVA for genetic covariances of matrix. Relations of index coefficients are marked with b1 for trait 1 and $b 2$ for trait 2 , which can be seen from the following formula:

$$
\frac{b_{2}}{b_{1}}=\frac{\delta^{2} \mathrm{P}_{1} \operatorname{CovA}-\operatorname{CovP} \delta^{2} \mathrm{~A}_{1}}{\delta^{2} \mathrm{P}_{2} \delta^{2} \mathrm{~A}_{1}-\operatorname{CovPCovA}}=\frac{\left(r A \mathrm{~h}_{2} / \mathrm{h}_{1}-\mathrm{rP}\right) \delta \mathrm{P}_{1}}{\left.1-\mathrm{rrAh}_{2} / \mathrm{h}_{1}\right) \delta \mathrm{P}_{2}}
$$

We can see that stated equation, beside genetic factors, includes also phenotypic variance, covariance and correlation, which all together influences the accuracy of the index. Depending on the situation, i.e. if in 
selection of rams parameters of half brothers, daughters or own physiological parameters are used, it is necessary to know $\delta \mathrm{P}_{1}{ }^{2}, \mathrm{~h}_{1}{ }^{2}$ or $\delta \mathrm{A}_{1}{ }^{2}$, CovA or $\mathrm{rAh} 2$, but not $\mathrm{rA} \mathrm{h} 2^{2}$ or $\delta \mathrm{A}_{2}{ }^{2}$.

If in construction of index two or more physiological characteristics were used, their genetic and phenotypic covariances are necessary (for instance CovA23).

\section{Conclusion}

Evaluation of genetic parameters which are significant for increase of fertility in sheep is subject of constant discussions and scientific analysis. The same question is asked over and over: which method of evaluation of genetic fertility parameters is optimal for given population in certain rearing conditions?

Regardless of the fact that accuracy of the evaluation of genetic fertility parameters is important factor in increase of number of lambs per female breeding animal, it is necessary to accept the reality that total accuracy doesn't exist.

Ideally, there would be an opportunity to determine which accuracy of the parameter evaluation is necessary, like for example in case of genetic covariance between traits.

This of course is not easy to determine, since all scientists engaged in genetics, statistics or physiology wouldn't be satisfied, therefore we must concur with saying that „accuracy is sufficient“, keeping in mind procedures which we use today.

Use of physiological quantitative parameters in sheep improvement in increase of fertility is one of the procedures which can lead to success in sheep selection on fertility.

\section{GENETSKO POBOLJŠANJE PLODNOSTI OVACA SELEKCIJOM PO FIZIOLOŠKIM KVANTITATIVNIM PARAMETRIMA}

M.P.Petrović, D. Ružić Muslić, M. Žujović, C. Mekić 


\section{Rezime}

U radu se razmatraju parametri plodnosti ovaca i analiziraju principi iznalaženja optimalnih metoda za njihovu procenu. Ističe se da su matematički postupci za procenu genetskih i fenotipskih parametara i predviđanje genetskih vrednosti danas uglavnom zasnovani na različitim linearnim i ne linearnim konceptima, pa je zbog toga potrebno prihvatiti realnost da potpuna tačnost za sada ne postoji. Poseban akcenat se stavlja na mogućnost korišćenja fizioloških kvantitativnih pokazatelja u selekciji ovaca na plodnost, s obzirom da postoji korelacija između između njih i osobina plodnosti. U tom smislu, analizira se stepen odgovora na direktnu i indirektnu selekciju unutar populacije, kako bi se ustanovila priroda parametara neophodnih za ocenu podataka i utvrdili relativni stepeni takvog odgovora

Ključne reči: ovca, plodnost, selekcija, fiziološki parametric

\section{References}

BANOS, G., LEWIS, R.M., NOTTER, D.R., AND. HOGUE, D.E. (2002): Genetic profile of fertility and prolificacy of maiden and mature ewes managed in a frequent lambing system. Proc. 7th World Congr. Genet. Appl. Livestock Prod. Publications on Hair Sheep, Parasite Resistance, and Easy-Care Sheep Genetics.

BINDON B.M, PIPER L.R, HILARD M.A (1996): Reproductive phisiologi and endocrinology of prolific sheep. CAB International, Wallingford, 453470.

BROMLEY, C.M., SNOWDER, G.D., VAN VLECK, L.D. (2000): Genetic parameters among weight, prolificacy, and wool traits in Columbia, Polypay, Rambouillet, and Targhee sheep. J. Anim.Sci.,; 78: 846-858.

DAVIS G.H., DODDS K.G., WHEELER R. AND JAY N.P. (2001): Evidence that an imprinted gene on the $\mathrm{X}$ chromosome increases ovulation rate in sheep Biology of Reproduction64 216-221.

DUGUMA, G., SCHOEMAN, S.J., CLOETE, S.W.P., JORDAAN, G.F (2002):Genetic and environmental parameters for ewe productivity in Merinos. S. Afr. J. Anim. Sci.,; 32: 154-159.

GALLOWAY S.M., MCNATTY K.P., CAMBRIDGE L.M. (2000): Mutations in anoocyte-derived growth differentiation factor gene (BMP15) cause increased ovulation rate and infertility in a dosage-sensitive manner 
Nature Genetics25 279283

GABRILIDIS G., PAPADOPOULOS T.,GEORGOUDIS A. (2000):Estimation of genetic parameters for production traits of chios sheep using a multitrait animal model. Livestock production science, 66,3, 217-221. Lidga C, GRANT W. MONTGOMERY, SUSAN M. GALLOWAY, GEORGE H. DAVIS AND KENNETH P. MCNATTY (2001): Genes controlling ovulation rate in sheep. Reproduction121, 843-852

HANFORD, K.J., VAN VLECK, L.D., SNOWDER, G.D. (2002): ESTIMATES OF GENETIC PARAMETERS AND GENETIC CHANGE FOR REPRODUCTION, WEIGHT, AND WOOL CHARACTERISTICS OF COLUMBIA SHEEP. J. ANIM. SCI.,;80: 3086-3098.

LEWIS, R. M., D. R. NOTTER, D. E. HOGUE AND B. H. MAGEE. ( 1996): EWE FERTILITY IN THE STAR ACCELERATED LAMBING SYSTEM. J. ANIM. SCI. 74:1511-1522.

MATOS, C.A.P., THOMAS, D.L., GIANOLA, D., TEMPELMAN, R.J.,YOUNG, L.D. (1997): Genetic analysis of discrete reproductive traits in sheep using linear and nonlinear models: I. Estimation of genetic parameters. J. Anim. Sci.; 75: 76-87

MATOS , D. L. THOMAS , D. GIANOLA, R. J. TEMPELMAN , AND L. D. YOUNG (1997): Genetic Analysis of Discrete Reproductive Traits in Sheep Using Linearand Nonlinear Models: I. Estimation of Genetic Parameters 1

NOTTER, D. R. (2000): Effects of ewe age and season of lambing on prolificacy in U.S. Targhee, Suffolk, and Polypay sheep. Small Ruminant Res. 38:1-7.

NOTTER, D. R. (2001): Genetic evaluation systems and the U.S. sheep industry. The Shepherd 46(12):18-19.

NOTTER D. R., CHEMINEAU. P. (2001):Nocturnal melatonin and prolactin plasma concentrations in sheep selected for fertility in autumn lambing 1 J. Anim. Sci. 2001. 79:2895-2901

NOTTER, D. R. (2002): Opportunities to reduce seasonality of breeding in sheep by selection. Sheep Goat Res. J. (In Press).

NOTTER, D. R., N. E. COCKETT, AND T. L. SHAY. (2002): Effect of the melatonin receptor 1a gene on fertility and litter size in sheep. Proc. 7th World Congr. Genet. Appl. Livestock Prod.

OKUT, H., C. M. BROMLEY, L. D. VAN VLECK, AND G. D. SNOWDER (1999): Genotypic expression at different ages: I. Prolificacy traits ofsheep. J. Anim. Sci. 77:2357-2365.

PEREZ-ENCISO M., J. L. FOULLEY”, L. BODIN, J. P. POIVEYF (1994): 
Genetic Implications of a Bivariate Threshold Modelfor Litter Size Components'. Journal of Animal Science, Vol 72, Issue 11 2775-2786 PETROVIĆ P. M., JOVANOVIĆ S., MEKIĆ C., TRENKOVSKI S. (1999): The relationship of genetic poliymorfism of haemoglobin and ewe quantitative traits. 5th. International Symposium. New trends in breeding farm animals. Belgrade October 6-8.

PETROVIĆ P.M. (1992): Ispitivanje reproduktivnih i proizvodnih osobina virtemberške rase ovaca (merinolandschaf). Doktorska disertacija, Univerzitet u Beogradu.

PETROVIĆ P.M., NENADIĆ M., SKALICKI Z.(1993): Genetski metodi povećanja plodnosti ovaca. Zbornik radova Polj. fak., Beograd, 91-97.

PETROVIĆ P.M., ŽUJOVIĆ M., NEGOVANOVIĆ D., VLAHOVIĆ M., MEKIĆ C., ALAVANTIĆ D. (1997): Stanje i perspektive oplemenjivanja ovaca.Biotehnologija u stočarstvu, 3-4, 83-87.

PETROVIĆ P.M., ŽUJOVIĆ M., SKALICKI Z., MEKIĆ C., STOJKOVIĆ M. (1994): Potrebe i mogućnosti genetskog unapredjenja našeg ovčarstva. Biotehnologija u stočarstvu, 10(5-6), 75-81.

PETROVIĆ P.M (2000): Genetika i oplemenjivanje ovaca (Monografija). Naučna knjiga, Beograd, 365 p.p

PETROVIĆ P.M., ŽUJOVIĆ M., NEGOVANOVIĆ D., STRSOGLAVEC, S., RUŽIĆ D. (2001): The importance of new selection methods in modern system of sheep breeding. International Symposium. Biotechnology in Animal Husbandry17,(5-6),p159-167

PETROVIĆ P.M., NEGOVANOVIĆ D., ŽUJOVIĆ M., RUŽIĆ, D., STRSOGLAVEC S. (2002): Multi purpose sheep production in.53 rd Annual Meet EAAP.,Cairo ,227

PETROVIĆ, P.M., ŽUJOVIĆ M., NEGOVANOVIĆ D., RUŽIĆ MUSLIĆ D., STRSOGLAVEC S. (2002): Neki aspekti savremene organizacije selekcijiskih postupaka u ovčarstvu. Savremena poljoprivreda, Vol.51, 3-4. 155-150.

PETROVIĆ P.M. (1996): Mis Ovca. Stvaranje mesnate rase ovaca, Institut za stočarstvo, Beograd-Zemun,60p.

RAO, S. AND D. R. NOTTER. (2000): Genetic analysis of litter size in Targhee, Suffolk, and Polypay sheep. J. Anim. Sci. 78:2113-2120.

RAO, S., NOTTER, D.R. (2000).: Genetic analysis of litter size in Targhee,Suffolk, and Polypay sheep. J. Anim. Sci., 78: 2113-2120.

SAKUL, H., G. E. BRADFORD, AND M. R. DALLY. (1999): Selection for litter size or weaning weight in range sheep: I. Selection practiced and direct response. Sheep Goat Res. J. 15:126-137. 
VAN WYK, J.B., FAIR, M.D., CLOETE, S.W.P. (2003): Revised models and genetic parameter estimates for production and reproduction traits in the Elsenburg Dormer sheep stud. S. Afr. J. Anim. Sci.,; 33: 213-222.

WILSON T., WU X-Y, JUENGEL J.L. (2001): Highly prolific Booroola sheep have a mutation in the intracellular kinase domain of bone morphogenetic protein $1 \mathrm{~B}$ receptor which is expressed in both oocytes and granulosa cells Biology of Reproduction 64 1225-1235

ZARAZAGA, L. A., MALPAUX, B., BODIN, L. AND CHEMINEAU。 P. (1998): The large variability in melatonin blood levels in ewes is under strong genetic influence. Am. J. Physiol. 274:E607-E610. 